\title{
The Relationship between Media Advertising and Attitudinal Changes during COVID-19
}

Keywords:

Posted Date: May 24th, 2021

DOI: https://doi.org/10.21203/rs.3.rs-77596/v2

License: (c) (i) This work is licensed under a Creative Commons Attribution 4.0 International License.

Read Full License 


\section{Abstract}

The authors have requested that this preprint be removed from Research Square. 